\title{
ANALISIS PENINGKATAN PERUSAHAAN DAN PROPORSI KEUANGAN DARI HARGA SAHAM
}

\author{
Oleh : \\ Arif Rakhman \\ Fakultas Ekonomi - Universitas Singaperbangsa Karawang \\ arif.rakhman@fe.unsika.ac.id \\ Angga Sanita Putra \\ Fakultas Ekonomi - Universitas Singaperbangsa Karawang \\ angga@fe.unsika.ac.id \\ Gusganda Suria Manda \\ Fakultas Ekonomi - Universitas Singaperbangsa Karawang \\ gusganda.suriamanda@fe.unsika.ac.id
}

\begin{tabular}{l}
\hline Article Info \\
\hline Article History: \\
Received 29 July - 2020 \\
Accepted 20 August - 2020 \\
Available Online \\
07 Sept - 2020
\end{tabular}

Keyword :

Company Growth, Capital

Structure, Stock Prices,

Property, Real Estate

\begin{abstract}
The purpose of this study is to analyze the effect of company growth and the effect of capital structure on the stock prices of Property and Real Estate. This study uses a quantitative approach, which is research that emphasizes its analysis of numerical data (numbers) that are processed by statistical methods. The research method used is descriptive verification method. The data source used is secondary data from the official website www.idx.co.id. The secondary data are the annual financial statements and ICMD of the Property and Real Estate subsector companies for the period of 2013 - 2018. Partially, the results of this study indicate that there is no significant effect of the Company's Growth on Stock Prices. In addition, the results of this study also indicate that there is an influence of the Capital Structure on Share Prices. While simultaneously, the results of this study indicate that there is a joint effect of Company Growth and Capital Structure on Share Prices.
\end{abstract}

\section{PENDAHULUAN}

Pasar modal merupakan salah satu indikator keadaan perekonomian suatu negara. Semakin tinggi indeks harga saham suatu pasar modal, maka dapat dikatakan semakin tinggi kepercayaan investor, sehingga semakin banyak investor yang menanamkan modalnya di pasar modal tersebut. Semakin meningkatnya minat masyarakat tentang pasar modal, jumlah perusahaan yang terdaftar di pasar modal yang semakin banyak, dan dukungan pemerintah melalui kebijakan berinvestasi.

Melalui pasar modal, perusahaan dapat memperoleh dana untuk melakukan kegiatan perekonomiannya. Jadi semakin tinggi harga saham berarti semakin banyak investor yang ingin menanamkan modalnya pada perusahaanperusahaan yang listing, maka geliat perekonomian suatu negara menjadi semakin baik. Saham perusahaan publik, sebagai komoditi investasi tergolong berisiko tinggi, karena sifat komoditasnya yang sangat peka terhadap perubahan yang terjadi, baik perubahan di luar negeri maupun di dalam negeri, perubahan politik, ekonomi, dan moneter. Perubahan tersebut dapat berdampak positif yang berarti naiknya harga saham atau berdampak negatif yang berarti turunnya harga saham. 
Berkaitan dengan sektor properti, optimisme perkembangan industri di sektor property dinilai cukup baik, hal ini dapat terlihat dari angka penanam modal yang dilakukan oleh investor asing. Kendati memiliki optimisme yang tinggi, ternyata tingkat penyerapan properti pada beberapa jenis properti tidak semuanya berjalan dengan baik. ada beberapa jenis properti yang justru kurang diminati bahkan ada beberapa yang mencapai titik terendah. Pada tahun 2017 daya beli masyarakat yang belum pulih di tunjuk sebagai lambatnya investasi sektor property. rendahnya daya beli masyarakat juga tercermin dari survei yang di lakukan Bank Indonesia (BI). Rendahnya daya beli masyarakat terhadap property itu diakibatkan karena harga property yang mahal, sehingga masyarakat sulit mengejar harga property yang menjulang tiap tahunnya sehingga banyak investor menarik investasi nya di beberapa perusahaan dikarenakan kurang menguntungkan dalam berbisnis property, tetapi saham sektor property masih memberikan keuntungan untuk perdaganan harian karena pergerakan saham property berfluktuasi tinggi (https://m.cnnindonesia.com).

Perusahaan property dan real estate di Indonesia dapat berkembang terlihat dari jumlah keuntungan perusahaan yang mana juga berdampak terhadap meningkatnya harga saham. Berikut perkembangan harga saham pada beberapa perusahaan sektor property dan real estate tahun 2013 - 2018 :

Gambar 1. Rata-Rata Harga Saham Perusahaan Sub Sektor Property dan Real Estate Tahun 20132017

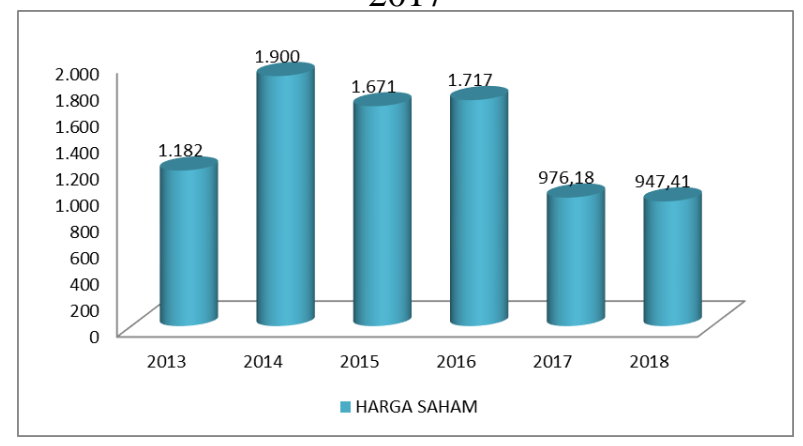

Sumber : Data Diolah Peneliti

Berdasakan Gambar diatas mengenai rata-rata harga saham Property dan Real Estate dapat di simpulkan bahwa kondisi harga saham perusahaan sub sektor Property dan Real Estate setiap tahunya mengalami kenaikan dan penurunan (fluktiatif). Rata-rata harga saham tertinggi yaitu sebesar 1.900. Sedangkan rata-rata saham terendah yaitu pada tahun 2018 yaitu 947,41. Penurunan harga saham tersebut di sebabkan banyak para investor yang menarik investasinya dari beberapa perusahaan property dan real estae sehingga harga saham turun lebih banyak ditahun 2017 dan 2018.
Pada prinsipnya semakin baik presentasi perusahaan dalam menghasilkan keuntungan, maka akan berpengaruh pula pada tingkat permintaan saham pada perusahaan tersebut sehingga saham ankan terus meningkat. Harga saham menjadi salah satu indikator yang menarik bagi investor dalam menginvestasikan dan membeli saham pada perusahaan .

Harga saham yang cukup tinggi akan memberikan keuntungan, yaitu berupa capital gain dan citra yang lebih baik bagi perusahaan sehingga memudahkan bagi manajemen untuk mendapatkan dana dari Iuar perusahaan untuk kegiatan perekonomian perusahaan. Harga saham dapat berubah secara cepat dalam beberapa menit maupun detik.

Naik turunnya harga saham seperti yang diuraikan di atas dapat dipengaruhi faktor internal perusahaan dan faktor eksternal perusahaan. Faktor internal yang berasal dari dalam perusahaan dapat dikendalikan oleh manajemen perusahaan sedangkan faktor eksternal yang berasal dari luar perusahaan tidak dapat dikendalikan oleh manajemen perusahaan.

Gambar 2 Rata-Rata Pertumbuhan Perusahaan Sub Sektor Property dan Real Estate Tahun 20132018

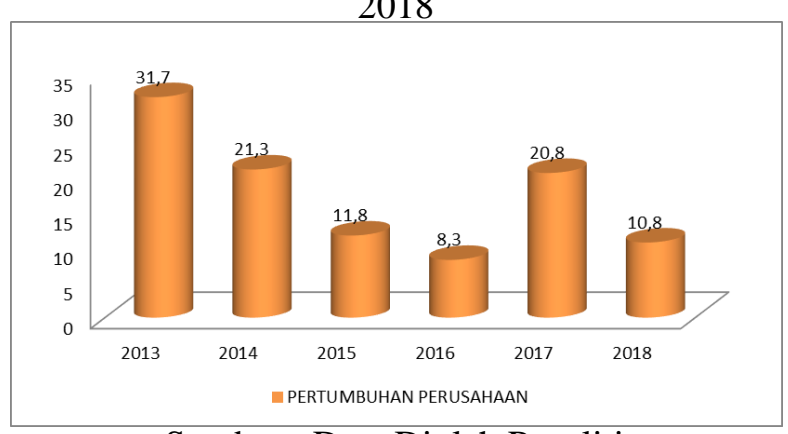

Sumber : Data Diolah Peneliti

Berdasarkan Gambar diatas mengenai rata-rata pertumbuhan perusahaandengan menggunakan perhitungan total aktiva terlihat mengalami fluktuatif (naik turun) setiap tahunnya. Pada tahun 2016 rata-rata pertumbuhan perusahaan mengalami penurunan cukup banayak. Rata-rata pertumbuhan perusahaan tertinggi yaitu pada tahun 2013 yakni 31,7. Sedangkan rata-rata pertumbuhan perusahaan terendah adalah tahun 2016 sebesar 8,3 . Pertumbuhan perusahaan sangat diharapkan oleh pihak internal maupun eksternal perusahaan, karena pertumbuhan yang baik memberi tanda bagi perkembangan perusahaan. dari sudut pandang investor, pertumbuhan suatu perusahaan merupakan tanda perusahaan memiliki aspek yang menguntungkan dan invetor pun mengharapkan tingkat pengembalian (rute of return). Pernyataan ini di dukung oleh penelitian Firmansyah (2017) yang menyatakan bahwa pertumbuhan perusahaan 
berpengaruh terhadap harga saham secara simultan.

Gambar 3 Rata-Rata Stuktur Modal Perusahaan Sub Sektor Property dan Real Estate Tahun 20132018

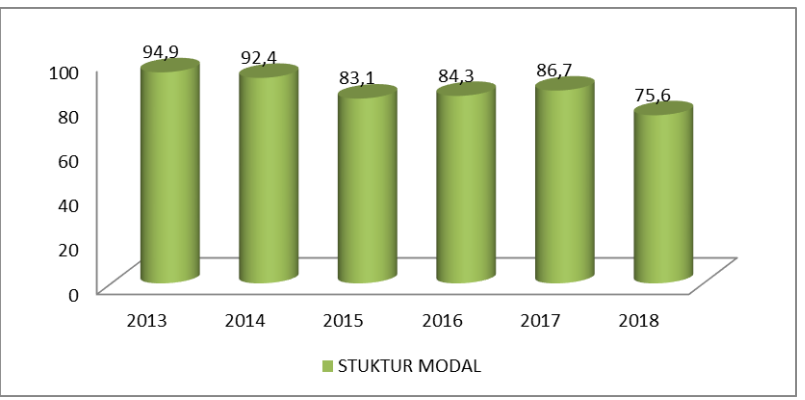

Sumber : Data Diolah Peneliti

Berdasarkan Gambar diatas mengenai rata-rata stuktur modal dengan menggunakan perhitungan Debt to Equity Ratio (DER) dari tahun 2013 sampai 2018 mengalami penurunan dan kenaikan. rata-rata penurunan struktur modal cukup banyak terjadi pada tahun 2018. Sedangkan rata-rata stuktur modal tertinggi yaitu pada tahun 2013. Bisa di disimpulkan bahwa hutang dalam stuktur modal ini lebih besar pada tahun 2013 sebesar 94,9 dan Paling rendah pada tahun 2018 sebesar 75,6.

Semakin besar DER menununjukan semakin besar biaya hutang yang harus di bayar perusahaan sehingga profitabilitas akan berkurang. Hal ini menyebabkan para pemegang saham berkurang dan akan berpengaruh terhadap minat investor yang akan mempengaruhi haraga saham yang semakin menurun. pada tahun 2014 dan 2016 ketika $D E R$ meningkat dilihat dari gambar perubahan harga saham juga meningkat seharusnya hal tersebut mempengaruhi minat investor untuk berinvestasi. Pada tahun 2017 perhitungan DER mengalami peningkatan dan harga saham pun terlihat menurun, hal tersebut berarti cukup mempengaruhi harga saham. Pernyataan ini di dukung oleh penelitian Randi Bayu Agusta,dkk (2018), Octaviani Mo'o,dkk (2018) menyatakan bahwa stuktur modal dengan memakai perhitungan $D E R$ berpengaruh signifikan terhadap harga saham.

Berdasarkan Penelitian Wehantouw dkk (2017). Pengaruh stuktur modal, Hasil dari penelitiannya menunjukkan struktur modal berpengaruh secara bersama terhadap harga saham. Penelitian Nino, dkk (2016). Stuktur Modal Hasil dari penelitiannya secara parsial memiliki pengaruh positif terhadap Harga Saham, Struktur Modal secara simultan memiliki pengaruh terhadap Harga Saham. Penelitian Gusti,A.P.(2018),hasil dari penelitiannya bahwa stuktur modal berpengaruh positif terhadap harga saham $12,4 \%$. Penelitian Nino,dkk (2016), hasil penelitiannya bahwa stuktur modal secara simultan memiliki pengaruh terhadap harga saham.
Berdasarkan Penelitian Indrayati (2018), Analisis Pengaruh Pertumbuhan Perusahaan Terhadap Harga saham . hasil dari penelitiannya Metode purposive sampling, pertumbuhan perusahaan berpengaruh tidak signifikan terhadap harga saham. Penelitian Firmansyah (2017), Pertumbuhan Perusahaan berpengaruh terhadap Harga Saham secara simultan.

\section{KAJIAN PUSTAKA PEGEMBANGAN HIPOTESIS}

DAN

\section{Teori Keagenan (Agency Theory)}

Prinsip utama dari teori keagenan adalah adanya hubungan kerja antara pihak yang memberi wewenang (principle) yaitu pemilik atau pemegang saham dengan pihak yang menerima wewenang (agent) yaitu manajer, dalam bentuk kontrak kerja sama . Masalah keagenan muncul karena terdapat konflik perbedaan pendapat (kepentingan) antara pemilik (principle) dengan manajemen (agent). hubungan keagenan merupakan suatu hubungan dimana pemilik perusahaan (principle) mempercayakan pengelolaan perusahaan oleh orang lain yaitu manajer (agent) sesuai dengan kepentingan pemilik (principle) dengan mendelegasikan beberapa wewenang pengambilan keputusan kepada manajer (agent). Manajer dalam menjalankan perusahaan mempunyai kewajiban untuk mengelola perusahaan sebagaimana diamanahkan oleh pemilik (principle) yaitu meningkatkan kemakmuran prinsipal melalui peningkatan nilai perusahaan, sebagai imbalannya manajer (agent) akan mendapatkan gaji, bonus atau kompensasi lainnya.Manajemen selaku pengelola perusahaan memiliki lebih banyak informasi tentang perusahaan, lebih mengetahui informasi internal, dan mengetahui prospek perusahaan di masa yang akan datang dibanding dengan pemilik atau pemegang saham, oleh karena itu manajer berkewajiban memberikan informasi atau sinyal mengenai kondisi perusahaan kepada pemilik. Tetapi informasi yang disampaikan terkadang tidak sesuai dengan kondisi perusahaan yang sebenarnya. Kondisi tersebut dikenal sebagai informasi yang tidak simetris atau asimetri informasi. Kenyataannya dalam menjalankan kewajibannya pihak manajer (agent) mempunyai tujuan lain yaitu mementingkan kepentingan mereka sendiri, memperoleh keuntungan yang sebesar-besarnya untuk meningkatkan kesejahteraan mereka, sehingga pada akhirnya menimbulkan konflik keagenan, yaitu konflik kepentingan antara manajemen (agent) dengan pemilik atau pemegang saham (principle)

\section{Akuntansi Keuangan}


Menurut martani (2016: 8) bahwa akuntansi keuangan berorientasi pada pelaporan pihak eksternal. Beragamnya pihak eksternal dengan tujuan spesifik bagi masing-masing pihak membuat pihak penyusunan laporan keuangan menggunakan prinsip dan asumsi-asumsi dalam penyusunan Iaporan keuangan. Untuk itu diperlukan standar akuntansi yang dijadlkan pedoman baik oleh penyusun maupun oleh pembaca Iaporan keuangan. Laporan yang dihasilkan dari akuntansi keuangan berupa laporan keuangan untuk tuiuan umum (general purpose financial statement).

\section{Laporan Keuangan}

Fahmi (2012:21) menyatakan laporan keuangan merupakan suatu informasi yang menggambarkan kondisi laporan keuangan suatu perusahaan, dan lebih jauh informasi tersebut dapat dijadikan sebagai gambaran kinerja keuangan perusahaan tersebut.

Laporan keuangan merupakan suatu hasil akhir dari proses akuntansi seiama periode tertentu. Laporan Keuangan disusun dan disajikan sekurang-kurangnya dalam masa satu periode atau setahun sekali.

Pengertian laporan keuangan sesuai dengan Pernyataan Standar Akuntansi Keuangan No.1 Revisi 2009 dalam kerangka dasar penyusunan dan penyaiian laporan keuangan, yaitu: "Laporan keuangan merupakan bagian proses dari proses pelaporan keuangan. Laporan keuangan yang lengkap biasanya meliputi neraca, laporan Iaba rugi, laporan posisi keuangan (yang dapat disajikan dalam berbagai cara seperti sebagai laporan arus kas atau laporan ams dana), atatan dan laporan lain serta materi penjelasan yang merupakan bagian integral dari laporan keuangan. Disamping itu juga tennasuk skedul dan informasi tambahan yang berkaitan dengan laporan tersebut, misalnya informasi keuangan segmen industri dan geograifis serta pengungkapan pengaruh perubahan harga".

\section{Analisis Laporan Keuangan}

Harahap (2011:190) mengungkapkan bahwa analisis Iaporan keuangan berarti menguraikan pos-pos |aporan keuangan menjadi unit informasi yang lebih kecil dan melihat hubungannya yang bersifat signifikan atau yang mempunyai makna antara satu dengan yang lain baik antara data kuantitatif maupun data non-kuantitatif dengan tujuan untuk mengetahui kondisl keuangan lebih dalam yang sangat panting dalam proses menghasilkan keputusan yang tepat.

Analisis laporan keuangan mencakup pengaplikasian berbagal alat dan teknik analisls pada Iaporan dan data keuangan dalam rangka untuk memperoleh ukuran-ukuran dan hubunganhubungan yang berguna dalam proses pengambilan keputusan. Analisis Iaporan keuangan juga merupakan senl mengubah data dari Iaporan keuangan ke lnformasi yang berguna bagl pengambil keputusan.

\section{Rasio Keuangan}

Bagi inivestor jangka pendek dan menengah pada dasarnya lebih banyak tertarik kepada keadaan keuangan jangka pendek dan kemampuan perusahaan untuk membayar dividen yang memadai (Randi Bayu Agusta,dkk 2018:102). Menurut Fahmi (2012:108) bahwa rasio keuangan adalah hubungan antara satu jumlah dengan jumlah Iainnya yang dapat memberikan gambaran relatif tentang kondisi keuangan dan prestasi perusahaan. Rasio keuangan sangat penting untuk melakukan analisa terhadap kondisl keuangan perusahaan dalam jangka pendek, menegah maupun langka panjang.

Menurut Kasmir (2015:104) pengertian rasio keuangan Rasio keuangan merupakan kegiatan membandingkan angka-angka yang ada dalam laporan keuangan dengan cara membagi satu angka dengan angka lainnya. Perbandingan dapat dilakukan antara satu komponen dengan komponen dalam satu Iaporan keuangan atau antarkomponen yang ada di antara Iaporan keuangan. Kemudian angka yang diperbandingkan dapat berupa angkaangka dalam satu periode maupun beberapa periode

Menurut Harahap (2013: 297) bahwa rasio keuangan adalah angka yang diperoleh dari hasil perbandingan dari suatu pos Iaporan keuangan dengan pos lainnva yang mempunyai hubungan yang relevan dan signifikan. Sedangkan menurut Samryn (2011: 409) bahwa rasio keuangan adalah suatu cara yang membuat perbandingan data keuangan perusahaan menjadi Iebih berarti. Rasio keuangan meniadi dasar untuk menjawab beberapa pertanvaan penting mengenai kesehatan keuangan dari perusahaan.

Berdasarkan pengertian diatas maka dapat disimpulkan bahwa rasio keuangan dapat menuniukkan kondisi keuangan perusahaan dan dari kondisi keuangan tersebut dapat mencerminkan kinerja keuangan perusahaan. ada beberapa jenis-jenis dari rasio keuangan.

\section{Pengukuran Rasio Solvabilitas (Leverage Ratio)}

Menurut Fahmi (2012: 59) bahwa raslo solvabilitas adalah rasio yang menunjukkan bagaimana perusahaan mampu untuk mengelola hutangnya dalam rangka memperoleh keuntungan dan juga 
mampu untuk melunasl kembali hutangnva . Sedangkan menurut Kasmir (2012:151) bahwa rasio solvabilitas adalah rasio yang digunakan untuk mengukur sejauh mana aktiva perusahaan dibiayai dengan utang. Dalam artl luas dikatakan bahwa rasio solvabilitas digunakan untuk mengukur kemampuaan perusahaan untuk membavar seluruh kewajibannya, balk jangka pendek maupun jangka panjang apabila perusahaan dibubarkan (dilikuidasi). Raslo solvabilitas yang digunakan dalam penelltian inl adalah Debt to Equity Ratio (DER).

\section{Pengukuran Pertumbuhan Perusahaan}

Pertumbuhan perusahaan sangat diharapkan oleh beberapa pihak baik pihak yang berasal dari internal maupun pihak yang berasal dari eskternal perusahaan dengan bertumbuhnya perusahaan diharapkan dapat memberikan naiknya nilai perusahaan di mata para investor (Firmansyah, 2017 : 111). Pertumbuhan perusahaan adalah seberapa jauh perusahaan menempatkan diri dalam sistem ekonomi secara keseluruhan atau sistem ekonomi untuk industri yang sama. pertumbuhan perusahaan merupakan perubahan total aset baik berupa peningkatan maupun penurunan yang dialami oleh perusahaan selama satu periode (satu tahun).Perusahaanperusahaan yang memiliki pertumbuhan yang cepat sering kali harus meningkatkan aktiva tetapnya. Dengan demikian, perusahaanperusahaan dengan tingkat pertumbuhan yang tinggi lebih banyak membutuhkan dana di masa depan dan juga lebih banyak menahan lama. pertumbuhan perusahaan diukur dari perubahan total aktiva. Rumus dari total Aktiva adalah sebagai berikut :

\section{Kesehatan Perusahaan}

$$
\Delta \mathrm{T}=\frac{\mathrm{TA}_{1}-\mathrm{TA}_{0}}{\mathrm{TA}_{0}}
$$

Menurut fahmi (2011:2) Kinerja keuangan adalah suatu analisis yang di lakukan untuk melihat sejauh mana suatu perusahaan telah melaksanakan dengan menggunakan aturan-aturan pelaksanaan keuangan secara baik dan benar.

\section{Stuktur Modal}

Struktur modal (capital structure) berhubungan dengan pembelian jangka panjang suatu perusahaan yang dihitung dengan membandingan utang jangka panjang dengan modal sendiri. Teori struktur modal menjelaskan apakah kebijkan pembelanjaan jangka panjang dapat mempengaruhi nilai perusahaan, biaya modal perusahaan dan harga pasar saham perusahaan (Sudana, 2015:164). Randi Bayu Agusta,dkk
(2018:103). stuktur modal dapat menggunakan perhitungan Debt to Equity Ratio.

Berikut ini akan dijelaskan tentang beberapa konsep struktur modal yang dikemukakan oleh para ahli sebagai berikut: Antara lain pendekatan tradisional, pendekatan laba operasi, teori trade off, agency theory, dan pecking order theory.

1. Pendekatan tradisional (traditional approach) Pendekatan ini mengasumsikan bahwa hingga leverage tertentu, risiko perusahaan tidak mengalami perubahan. Sehingga baik tingkat bunga hutang maupun tingkat kapitalisasi relatif konstan.

2. Pendekatan laba operasi (net operating income approach)

Pendekatan ini melihat bahwa biaya modal ratarata tertimban konstan berapapun tingkat hutang yang digunakan oleh perusahaan. Pertama, diasumsikan bahwa biaya hutang konstan seperti halnya dalam pendekatan laba bersih. Kedua, penggunaan hutang yang semakin besar oleh pemilik modal sendiri dilihat sebagai peningkatan risiko perusahaan.

3. Agency costs

Agency costs atau biaya keagenan adalah biaya yang timbul karena perusahaan menggunakan hutang dan melibatkan hubungan antara pemilik perusahaan (pemegang saham) dan kreditor.

4. Trade off theory

Teori ini menjelaskan mengenai keseimbangan antara biaya dan manfaat akibat berhutang. Trade of theory ini juga menjelaskan bahwa ketika manfaat berhutang lebih besar dibandingkan dengan biaya berhutang, maka perusahaan diuntungkan dari berhutang tersebut. sebaliknya.

5. Pecking Order Theory

Menurut Suad Husnan (2010: 324-325), Pecking Order Theory menyatakan bahwa :

1. Perusahaan menyukai internal financing (pendanaan dari hasil operasi perusahaan)

2. Perusahaan Mencoba Menyesuaikan rasio pembagian dividen yang di targetkan, dengan berusaha menghindari perubahan pembayaran dividen secara drastis.

3. Kebijakan dividen yang relatif segan untuk di ubah, disertai fluktuasi profitabilitas dan kesempatan investasi yang tidak bisa di di duga.

4. Apabila dana dari luar (external financing) diperlukan maka perusahaan akan menerbitkan sekuritas yang paling aman terlebih dahulu. 


\section{Saham}

Saham adalah surat tanda pemilikan atas perusahaan yang menjual saham tersebut. pengertian saham ini artinya surat berharga yang dikeluarkan oleh sebuah perusahaan yang berbentuk Perseroan Terbatas (PT) atau yang biasa disebut emiten. Saham menyatakan bahwa pemilik saham tersebut juga pemilik sebagian dari perusahaan itu dengan demikian . Wujud saham adalah selembar kertas yang menerangkan bahwa pemilik kertas itu adalah pemilik perusahaan yang me-nerbitkan kertas tersebut. Jadi sama dengan menabung di bank, setiap kali kita menabung maka kita akan mendapat $\neg$ kan slip yang menjelaskan bahwa kita telah menyetor sejum $\neg$ lah uang. Dalam investasi saham, yang kita terima bukan slip melainkan saham dengan demikian saham adalah surat berharga yang menunjukkan kepemilikan perusahaan (Elis Listiana Mulyani, 2015:16). Dengan memiliki saham suatu perusahaan maka investor akan mempunyai hak terhadap pendapatan dan kekayaan perusahaan. setelah dikurangi dengan pembavaran semua kewaiiban perusahaan. Menurut Fahmi (2012:81) bahwa Saham merupakan salah satu instetment pasar modal yang paling banyak diminati oleh investor, karena mampu memberikan tingkat pengembalian yang menarik.

\section{Kerangka Pengembangan Hipotesis}

Peneliti melakukan pengujian pada Pertumbuhan Perusahaan dan Stuktur Modal Terhadap Harga Saham. Adapun Kerangka pemikiran dalam penelitian ini sebagai berikut :

\section{Pengaruh Pertumbuhan Perusahaan Terhadap Harga Saham}

Pertumbuhan perusahaan (company growth) adalah peningkatan atau penurunan toal aset yang dimiliki oleh perusahaan. pertumbuhan perusahaan dihitung sebagai presentase perubahan aset pada tahun tertentu terhadap tahun sebelumnya. Pertumbuhan assets diukur dengan mengurangi assets tahun sekarang dengan assets tahun sebelumnya dibagi dengan aset tahun sebelumnya. Pernyataan ini di dukung oleh penelitian (Firmansyah, 2017 : 111) yang menyatakan bahwa pertumbuhan perusahaan berpengaruh terhadap harga saham secara simultan.

\section{Pengaruh Stuktur Modal Terhadap Harga Saham}

Struktur modal (capital structure) membandingan utang jangka panjang dengan modal sendiri. Teori struktur modal menjelaskan apakah kebijkan pembelanjaan jangka panjang dapat mempengaruhi biaya modal perusahaan dan harga pasar saham perusahaan (Sudana, 2015:164). Pengukuran
Stuktur Modal di ukur dengan menggunakan Total Liability di bagi Total Ekuitas. Pernyataan ini di dukung oleh penelitian Randi Bayu Agusta,dkk (2018), Octaviani Mo'o,dkk (2018) menyatakan bahwa stuktur modal dengan memakai perhitungan DER berpengaruh signifikan terhadap harga saham.

Pengaruh Pertumbuhan Perusahaan dan Stuktur Modal Terhadap Harga Saham

Pertumbuhan perusahaan adalah seberapa jauh perusahaan menempatkan diri dalam sistem ekonomi secara keseluruhan atau sistem ekonomi untuk industri yang sama. Struktur modal (capital structure) membandingan utang jangka panjang dengan modal sendiri. Teori struktur modal menjelaskan apakah kebijkan pembelanjaan jangka panjang dapat mempengaruhi biaya modal perusahaan dan harga pasar saham perusahaan. Harga saham adalah nilai nominal penutupan (Closing Price) dari pernataan atau pemilikan seseorang atau badan dalam suatu perusahaan atau perseroan terbatas yang berlaku secara legular di pasar modal indonesia (Randi Bayu Agusta,dkk 2018). Keberhasilan dalam munghasilkan keuntungan akan memberikan kepuasan bagi investor yang rasional.

Baik Pertumbuhan Perusahaan dan Stuktur Modal keduanya mempunyai peranan penting bagi perusahaan tersebut dalam rangka melihat naik turun nya suatu harga saham pada perusahaan dengan melihat keadaan laporan keuangan perusahaan tersebut dan banyak para investor diluaran sana yang banyak melihat aporan keuangan yang deperlihatkan oleh perusahaan. pernyataan ini di dukung oleh penelitian Gusti,A. P. (2018), Muktiadji dan Ningrum (2018) dan Firmansyah (2017 : 111).

\section{METODE PENELITIAN}

Penelitian ini menggunakan pendekatan kuantitatif, yaitu penelitian yang menekankan analisanya pada data-data numerical (angka) yang di olah dengan metoda statistika.

Menurut Sugiyono (2014:13) metode penelitian kuantitatif adalah metode penelitian kuantitatif dapat diartikan sebagi metode penelitian yang berlandasan pada fllsafat positivisme, digunakan untuk menehti pada populasi atau sampel tertentu, pengumpulan data menggunakan instrumen penelitian.

Instrumen penelitian adalah suatu alat yang di gunakan mengukur fenomena alam maupun sosial yang di minati. Secara sfesifik semua fenomena ini di sebut variabel peneitian. Instrumen yang di gunakan dalam penelitian ini yaitu : 
Tabel 1. Instrument Penelitian

\begin{tabular}{|c|c|c|}
\hline Variabel & Definisi & Pengukuran \\
\hline $\begin{array}{l}\text { Pertumbuhan } \\
\text { Perusahaan } \\
\text { (Firmansyah, } \\
2017: 111 \text { ). }\end{array}$ & \begin{tabular}{lr}
\multicolumn{2}{l}{ Pertumbuhan } \\
Perusahaan & diukur \\
dengan menggunakan & aktiva. \\
total & \\
Pertumbuhan & \\
perusahaan & adalah \\
selisih total aktiva yang \\
dimiliki & oleh \\
perusahaan & pada \\
periode & sekarang \\
dengan & periode \\
sebelumnya & terhadap \\
total aktiva & periode \\
berikutnya. &
\end{tabular} & $\begin{array}{l}\text { Total Aset } \\
\text { Tahun Sekarang } \\
\text { Total Aset } \\
\text { Tahun } \\
\text { Sebelumnya }\end{array}$ \\
\hline $\begin{array}{l}\text { Stuktur Modal } \\
\text { (Sudana,2015: } \\
164 \text { ) }\end{array}$ & $\begin{array}{lr}\begin{array}{l}\text { Struktur } \\
\text { merupakan }\end{array} & \text { Modal } \\
\text { perbandingan } & \text { total } \\
\text { hutang yang } & \text { dimiliki } \\
\text { perusahaan } & \text { terhadap } \\
\text { total } & \text { ekuitas } \\
\text { perusahaan. } & \text { Struktur } \\
\text { modal diukur } & \text { dengan } \\
\text { Debt to Equity } & \text { Ratio } \\
\text { (DER). Debt to Equity } \\
\text { Ratio adalah } & \text { suatu } \\
\text { upaya } & \text { untuk } \\
\text { memperlihatkan dalam } \\
\text { format lain, proporsi } \\
\text { relatif dari } & \text { klaim } \\
\text { pemberi } & \text { pinjaman } \\
\text { terhadap } & \text { hak } \\
\text { kepemilikan } & \text { dan } \\
\text { digunakan rangai } \\
\text { ukuran peranan hutang. }\end{array}$ & $\begin{array}{l}\text { TotalLiabilities } \\
\text { Total Equity }\end{array}$ \\
\hline $\begin{array}{l}\text { Harga Saham } \\
\text { (Menurut } \\
\text { Darmadji } \\
2012: 102 \text { ) }\end{array}$ & $\begin{array}{l}\text { Harga saham adalah } \\
\text { harga atau nilai uang } \\
\text { yang bersedia di } \\
\text { keluarkan untuk } \\
\text { memperoleh atas suatu } \\
\text { saham. }\end{array}$ & Clossing Price \\
\hline
\end{tabular}

Sumber : Kajian Peneliti,2019

Populasi dalam penetitian ini adalah laporan keuangan tahunan 4O Perusahaan Subsektor Property dan Real Estate yang Terdaftar di Bursa Efek Indonesia (BEI) Periode Tahun 2013-2018.

Teknik pengambilan sampel yang digunakan dalam penelitian ini adalah purposive sampling Menurut Sugiyono (2014:68) yaitu "Teknik Penentuan sampel dengan pertimbangan tertentu. Teknik ini dipilih karna adanya beberapa pertimbangan, yaitu faktor waktu,tenaga dan biaya yang terbatas, dengan teknik ini peneliti dapat menentukan sampel berdasarkan tujuan tertentu, tetapi tetap memaatuhi syarat-syarat yang berlaku. Adapun syarat yang di tentukan adalah sebagai berikut: a. Perusahaan subsektor Property dan Real Estate Yang terdaptar Di Bursa Efek Indonesia (BEI) Periode Tahun 2013-2018.

b. Perusahaan mempublikasikan laporan keuangan di indonesian Capital Market Directory (ICMD) Selama tahun 2013-2018

c. Perusahaan yang menyajikan laporan keuangan tahunan periode pengamatan tahun 2013-2018

d. Perusahaan memiliki kelengkapan data yang di perlukan dalam penelitian sesuai dengan variabel yang di teliti yaitu Pertumbuhan Perusahaan dan Stuktur Modal dan Harga Saham.

Berdasarkan kriteria yang telah di tentukan maka jumlah sample perusahaan dalam penelitian ini dapat dilihat pada tabel 3.2 berikut ini :

Tabel 2. Pemilihan Sampel

\begin{tabular}{|c|c|c|}
\hline No & Kriteria Sampel & $\begin{array}{c}\text { Jumlah } \\
\text { Perusahaan }\end{array}$ \\
\hline 1 & $\begin{array}{lr}\text { Perusahaan subsektor } \\
\text { Prpperty dan Real } \\
\text { Estate yang terdaftar } \\
\text { di Bursa } & \text { Efek } \\
\text { Indonesia } & \text { (BEI) } \\
\text { periode Tahun } & 2013- \\
2018 & \end{array}$ & 40 \\
\hline 2 & $\begin{array}{l}\text { Perusahaan } \\
\text { Menyajikan Laporan } \\
\text { Keuangan Tahunan } \\
\text { Periode Pengamatan } \\
\text { Tahun 2013-2018 }\end{array}$ & 12 \\
\hline 3 & $\begin{array}{l}\text { Perusahaan } \\
\text { Mempunyai } \\
\text { Kelengkapan data } \\
\text { yang di perlukan } \\
\text { dalam penelitian } \\
\text { sesuai dengan } \\
\text { variabel yang di teliti } \\
\text { yaitu Pertumbuhan } \\
\text { Perusahan dan } \\
\text { Stuktur Modal }\end{array}$ & 12 \\
\hline
\end{tabular}

Sumber : kriteria sampel oleh peneliti (data diolah), 2019

Berdasarkan Kriteria yang telah ditentukan, dari jumlah emiten sebanyak 40 perusahaan maka yang akan menjadi sampel hanya 12 perusahaan, sehingga total pengamatan data dari tahun 20132018 adalah sebanyak 72 data. Perusahaan yang menjadi sampel penelitian pada tabel 3.3 sebagai berikut: 
Tabel 3. Daftar Nama Perusahaan Yang Menjadi Sampel

\begin{tabular}{|c|l|l|}
\hline No & $\begin{array}{c}\text { Kode } \\
\text { Perusahaan }\end{array}$ & \multicolumn{1}{|c|}{ Nama Perusahan } \\
\hline 1 & PWON & Pakuwon Jati Tbk \\
\hline 2 & MTLA & Metropolitan Land Tbk \\
\hline 3 & MDLN & Moderland Reality Tbk \\
\hline 4 & GPRA & Perdana Gapura Prima Tbk \\
\hline 5 & LPCK & Lippo Cikarang Tbk \\
\hline 6 & EMDE & Megapolitan Development Tbk \\
\hline 7 & APLN & Agung Podomoro Land Tbk \\
\hline 8 & RDTX & Roda Vivatex Tbk \\
\hline 9 & RODA & Pikko Land Development Tbk \\
\hline 10 & SMRA & Summarecon Agung Tbk \\
\hline 11 & LPKI & Lippo Karawaci Tbk \\
\hline 12 & CTRA & Ciputra Development Tbk \\
\hline
\end{tabular}

Sumber : Data yang diolah 2019

Analisis Regresi Linier Berganda dipakai untuk mengetahui pengaruh masing-masing variabel independen yaitu Pertumbuhan Perusahaan dan Stuktur Modal Terhadap Harga Sahamadalah dengan menggunakan analisis regresi. Hubungan fungsi antara satu variabel dependen dengan lebih dari satu variabel independen dapat dilakukan dengan model regresi dimana Pertumbuhan Perusahaan dan Stuktur Modal sebagai variabel independen, sedangkan harga saham sebagai variabel dependen.

\section{HASIL DAN PEMBAHASAN}

Penelitian ini di Bursa Efek Indonesia di perusahaan subsektor Property dan Real Estate tentang Pengaruh Pertumbuhan Perusahaan dan Stuktur Modal Terhadap Harga Saham selama 6 (Enam) tahun yaitu periode 2013-2018 dengan sampel 12 perusahaan yang akan diteliti dengan jumlah 72 data. Analisis data yang dilakukan dalam penelitian adalah dengan analisis statistik menggunakan bantuan Software SPSS versi 25. Adapun hasil pengujian yang telah dilakukan dalam penelitian akan dijelaskan sebagai berikut.

Pertumbuhan Perusahaan Property dan Ral Estate tahun 2013-2018

Berdasarkan hasil penelitian yang telah dilakukan dan di lihat dari hasil penelitian pertumbuhan perusahaan pada 12 perusahan Property dan Real Estate selama enam tahun di mulai dari 2013 sampai 2018, menunjukan nilai rata-rata per tahun mengalami Naik Turun setiap tahunnya. Data rata-rata Pertumbuhan Perusahaan pada tahun 2013 sebesar 0,317 (31,7) dan terus mengalami penurunan pada 3 tahun berikutnya yaitu tahun 2014 rata-rata pertumbuhan perusahaan mengalami penurunan sebesar $0,213(21,3)$. Tahun 2015 rata-rata pertumbuhan perusahaan mengalami penurunan sebesar $0,118(11,8)$. Tahun 2016 rata-rata pertumbuhan perusahaan mengalami penurunan sebesar $0,083(8,3)$. Pada tahu 2017 mengalami peningkatan rata-rata pertumbuhan perusahaan sebesar 0,208 $(20,8)$ dan kembali mengalami penurunan rata-rata pertumbuhan perusahaan pada tahun 2018 sebesar $0,108(10,8)$.

Kenaikan terdapat pada PT Lippo Cikarang Tbk pada tahun 2017, sedangkan mengalami penurunan terdapat pada PT Lippo Cikarang Tbk pada tahun 2018. Kenaikan dan penurunan disebabkan karena pertumbuhan perusahan diperoleh dari perhitungan total aset tahun sekarang dikurang total aset tahun sebelumnya dibagi total aset tahun sebelumnya. Maka meningkatnya pertumbuhan perusahaan diakibatkan karena pada tahun 2017 PT Lippo Cikarang Tbk memperoleh total aset tahun sekarangnya sebesar 12.378 .227 sedangkan pada tahun 2018 PT Lippo Cikarang Tbk total aset tahun sekarangnya sebesar 9.225.622 yang mengakibatkan pertumbuhan perusahaan menurun. Dengan demikian, setiap perubahan pertumbuhan perusahaan dari perhitungan total aset dapat mengakibatkan perubahan pertumbuhan perusahaan. Menurut Firmansyah (2017:111) pertumbuhan perusahaan adalah peningkatan atau penurunan total aset yang dimiliki oleh perusahaan. pertumbuhan perusahaan dihitung sebagai presentase perubahan aset pada tahun tertentu terhadap tahun sebelumnya.

\section{Stuktur Modal Perusahaan Property dan Ral Estate tahun 2013-2018}

Berdasarkan hasil penelitian yang dilakukan dan dilihat dari hasil penelitian Stuktur Modal pada 12 perusahan Property dan Real Estate selama 2013 sampai 2018, menunjukan nilai ratarata per tahun mengalami Naik Turun. Data ratarata Stuktur modal pada tahun 2013 sebesar 0,949 $(94,9)$ dan terus mengalami penurunan pada 2 tahun berikutnya yaitu tahun 2014 rata-rata stuktur modal mengalami penurunan sebesar $0,924(92,4)$. Tahun 2015 rata-rata stuktur modal mengalami penurunan sebesar $0,831(83,1)$. Tahun 2016 ratarata pertumbuhan perusahaan mengalami peningkatan sebesar 0,843 (84,3). Pada tahu 2017 mengalami peningkatan rata-rata pertumbuhan perusahaan sebesar $0,867 \quad(86,7)$ dan kembali mengalami penurunan rata-rata pertumbuhan perusahaan pada tahun 2018 sebesar $0,756(75,6)$.

Kenaikan stuktur modal terjadi pada PT Summarecon Agung Tbk (SMRA) pada tahun 2013, sedangkan stuktur modal mengalami penurunan terdapat pada PT Roda Vivatex Tbk pada tahun 2014. Kenaikan penurunan stuktur modal terjadi karena nilai stuktur modal di peroleh dari perhitungan nilai hutang dibagi nilai modal. Maka meninkatnya stuktur modal diakibatkan dikarenakan PT Summarecon Agung Tbk pada tahun 2013 nilai hutangnya 9.001 dan modalnya 
4.658 yang mengakibatkan hutangnya lebih besar, sedangkan pada tahun 2014 PT Roda Vivatex Tbk nilai hutangnya 291.667 dan modalnya 1.351 .774 yang mengakibatkan modalnya lebih besar dari pada hutang maka dari itu menurun stuktur modalnya. Dengan demikian, setiap perubahaan hutang dan modal perusahaan mengakibatkan stuktur modal berubah. Menurut Teori Sudana (2015:164) stuktur modal berhubungan dengan pembelian jangka panjang suatu perusahaan yang dihitung dengan membandingkan utang jangka panjang dengan modal sendiri.

\section{Harga Saham Perusahaan Property dan Ral Estate tahun 2013-2018}

Berdasarkan hasil penelitian, harga Saham Perusahaan pada 12 perusahan Property dan Real Estate di Bursa Efek Indonesia dengan penelitian enam tahun yaitu dimulai periode 2013 sampai 2018, menunjukan hasil nilai rata-rata per tahun mengalami naik turun setiap tahunnya selalu berbeda. Data rata-rata harga saham pada tahun 2013 sebesar 1.182 dan terus mengalami peningkatan pada tahun berikutnya yaitu tahun 2014 rata-rata harga saham sebesar 1.900. Tahun 2015 rata-rata harga saham mengalami penurunan sebesar 1.671. Tahun 2016 rata-rata harga saham mengalami kenaikan sebesar 1.717 dan 2 tahun berikutnya mengalami penurunan Tahun 2017 ratarata harga saham mengalami penurunan sebesar 976,18. Pada tahu 2018 mengalami penurunan ratarata harga saham sebesar 947,41.

Harga saham diperoleh dari penutupan harga saham (closing price). Kenaikan harga saham terdapat pada perusahaan PT Lippo Cikarang Tbk 2014, sedangkan penurunan terjadi pada PT Lippo Cikarang Tbk 2015. Kenaikan dan penurunan terjadi karena pada tahun 2014 harga saham PT Lippo Cikarang Tbk sebesar 10.400 sedangkan PT Lippo Cikarang Tbk pada tahun 2015 sebesar 7.250 yang mengakibatkan penurunan harga saham. Dengan demikian, setiap naik turunnya harga saham mengakibatkan perubahan harga saham. Menurut teori Darmadji (2012:102) menyatakan bahawa adalah nominal penutupan (closing price) harga saham bisa berubah naik ataupun turun dalam hitungan waktu.

Pengaruh Pertumbuhan Perusahaan Terhadap Harga Saham Property dan Real Estate tahun 2013-2018

Pertumbuhan Perusahaan dalam penelitian ini diukur dengan menggunakan Total Aktiva. Berdasarkan hasil analisis regresi linier berganda Pertumbuhan Perusahaan berpengaruh positif terhadap jumlah harga saham yang terserap oleh perusahaan subsektor Property dan Real Estate yang ada di BEI dengan koefisien regresi sebesar 0,202 dimana artinya jika Pertumbuhan
Perusahaan dinaikan sebesar $1 \%$ maka akan menyebabkan kenaikan jumlah Harga Saham sebesar $0,202 \%$.

Berdasarkan Hasil Pengujian Hipotesis variabel Pertumbuhan Perusahaan (PP) diketahui sebesar $0,055<0,05$, maka secara parsial Pertumbuhan Perusahaan tidak terdapat signifikan terhadap harga saham. Diperoleh t-hitung 1,951 dan derajat bebas (n-k) atau 67-2= 65 diperoleh angka t-tabel sebesar 1,997 sehingga t-hitung $<\mathrm{t}$ tabel. Artinya $H_{O}$ diterima dan $H_{a}$ ditolak, maka tidak terdapat pengaruh antara Pertumbuhan Perusahaan terhadap Harga Saham.

Pengaruh Stuktur modal Terhadap Harga Saham Property dan Real Estate tahun 20132018

Stuktur Modal dalam penelitian ini diukur menggunakan Debt To Equity Ratio (DER). Berdasarkan hasil analisis regresi linier berganda bahwa Stuktur Modal berpengaruh negatif terhadap jumlah harga saham yang terserap oleh perusahaan subsektor Property dan Real Estate yang ada di BEI dengan koefisien regresi sebesar 0,520 dimana artinya jika Stuktur Modal dinaikan sebesar $1 \%$ maka akan menyebabkan penurunan jumlah Harga Saham sebesar 0,520\%.

Berdasarkan Hasil Pengujian Hipotesis variabel Stuktur Modal (SM) diketahui sebesar $0,003<0,05$, maka secara parsial Stuktur Modal terdapat signifikan terhadap harga saham. Diperoleh t-hitung -3,127 dan derajat bebas (n-k) atau $67-2=65$ diperoleh angka t-tabel sebesar 1,997 sehingga t-hitung $>$ t-tabel. Artinya $H_{O}$ ditolak dan $H_{a}$ diterima, maka terdapat pengaruh antara Stuktur Modal terhadap Harga Saham.

Pengaruh Pertumbuhan Perusahaan dan Stuktur modal Terhadap Harga Saham Property dan Real Estate tahun 2013-2018

Berdasarkan hasil uji hipotesis pada pada uji simultan (Uji F) dapat diketahui bahwa nilai sig sebesar $0,001<0,05$. Diperoleh $\mathrm{f}-$ hitung 7,340 dan derajat bebas Df1 $=2$ dan Df2 $=64$ didapat $(2 ; 64)$ diperoleh angka f-tabel sebesar 3,14 sehingga fhitung > f-tabel. Artinya bahwa Pertumbuhan Perusahaan dan Stuktur Modal berpengaruh secara simultan terhadap harga saham. Berdasarkan hasil uji Koefisien Determinasi dapat diketahui bahwa niali yang di dapat untu $\mathrm{R}$ Squere sebesar 0,187 atau sebesar $18,7 \%$. Hal ini menunjukan bahwa variabl yang di teliti yaitu Pertumbuhan Perusahaan dan Stuktur Modal Berpengaruh Sebesar $18,7 \%$ terhadap harga saham. Sedangkan sisanya yaitu sebesar $81,3 \% \quad(100 \%-18,7 \%)$ dipengaruhi oleh variabel yang tidak teliti dalam penelitian ini. 


\section{KESIMPULAN}

Berdasarkan hasil penelitian dan pembahasan tentang Pengaruh Pertumbuhan Perusahaan dan Stuktur Modal terhadap Harga Saham pada perusahaan subsektor Property dan Real Estate yang terdaftar di BEI pada tahun 2013 sampai dengan tahun 2018, maka dibuatkan kesimpulan sebagai berikut :

a. Berdasarkan hasil penelitian yang dilakukan dan dilihat dari hasil penelitian pertumbuhan perusahaan pada 12 perusahan Property dan Real Estate selama 2013 sampai 2018, menunjukan nilai rata-rata per tahun mengalami naik turun setiap tahunnya.

b. Berdasarkan hasil penelitian yang dilakukan dan dilihat dari hasil penelitian Stuktur Modal pada 12 perusahan Property dan Real Estate selama 2013 sampai 2018, menunjukan nilai rata-rata per tahun mengalami naik turun.

c. Berdasarkan hasil penelitian, harga Saham Perusahaan pada 12 perusahan Property dan Real Estate di Bursa Efek Indonesia dengan penelitian enam tahun yaitu dimulai periode 2013 sampai 2018, menunjukan hasil nilai rata-rata per tahun mengalami naik turun setiap tahunnya selalu berbeda.

d. Tidak terdapat pengaruh dari pertumbuhan perusahaan yang diukur dengan total aktiva terrhadap harga saham di perusahaan subsektor Property dan Real Estate yang ada di BEI.

e. Terdapat Pengaruh dari Stuktur Modal yang diukur dengan Debt To Equity Ratio (DER) Terhadap Harga Saham di perusahaan subsektor Property dan Real Estate yang ada di BEI.

f. Terdapat pengaruh secara simultan dari Pertumbuhan Perusahaan dan Stuktur Modal Terhadap Harga Saham di perusahaan subsektor Property dan Real Estate yang ada di BEI.

\section{REFERENSI}

Anamaria, P., Parengkuan, T., \& Joy E.T.(2018). pengaruh profitabilitas dan stuktur kepemilikan terhadap harga saham. Jurnal EMBA Vol.6 No.4 September 2018, Hal. 3048 - 3057ISSN 2303-1174.

Ardiyansyah, I., \& isbanah,Y.(2017). Analisis Pengaruh Dividen, Pertumbuhan Aset, Ukuran Perusahaan dan Leverage Terhadap Validasi Harga Saham.Jurnal Riset Akuntansi \& Keuangan.ISSN : 23381507.

Brigham dan Houston. 2015. Dasar-Dasar Manajemen Keuangan. Jakarta : salemba empat.
Darmadji, T dan Henry ,M.F. 2012. Pasar Modal Di indonesia. Jakarta: Salemba Empat.

Dr. Nandan V. (2017).Impact of EPS and DPS On Stock Price Prestige International Journal of Management \& IT-Sanchayan, Vol. 6(1), 2017, pp. 111-121, ISSN: 2277$1689,2278-8441$.

Elis, L., M., \& Usman, M,. K. (2015). Analisis Determinasi Volume Penjualan Saham dan Tingkat Bunga Terhadap Harga Saham.Jurnal Ekonomi Manajemen Volume 1 Nomor 1 (November 2015) 1521 ISSN 2477-2275.

Elly, S.(2018). Pengaruh Earning Per Share, Pembagian Dividen, Laba Bersih danPertumbuhan Penjualan Terhadap Perubahan Harga Saham Proceeding of Management : Vol.5, No.3 Dsember 2018 ISSN : 2355-9357.

Fahmi,Irham. $2012 \quad$.Analisis Kinerja Keuangan.Alfabeta.Bandung

Firmansyah,M. (2017). Pengaruh Pertumbuhan Perusahaan, Total Asset Turnover,Return On Investment,Earning Per Share Terhadap Harga Saham. Asian Journal of Innovation and Entrepreneurship (e-ISSN: 2477- 0574; p-ISSN: 2477-3824) Vol. 02

Ghozali, Imam.2011. Aplikasi Analisis Multivariate dengan Program IBM SPSS 23.Semarang: BPFE niversitas Diponogoro.

Gusti,A. P. (2018). The Effect Of Capital Structure and Profitability On Stock Price (Study Of The Manufacturing Sector in Indonesia Stock Exchange). Jurnal ISSN.

Gabriella, C., S., Paulina, V.R., \& Victoria, N.(2018). Pengaruh Stuktur Modal Dan ROA Terhadap Harga Saham Jurnal EMBA Vol.6 No.4 September 2018, Hal. 2758 - 2767.ISSN 2303-1174.

2016. Aplikasi Analisis Multivariate dengan Program IBM SPSS 23.Semarang: BPFE niversitas Diponogoro.

Harahap, S.S. 2013. Analisis Kritis Atas Laporan Keuangan. Edisi Kesebelas. Jakarta: Rajawali Pers.

Husnan,S. 2010. Manajemen Keuangan Teori dan Penerapan (Keputusan Jangka Panjang).Edisi Keempat. BPFE: Yogyakarta.

Hartanto \& Diansyah .(2018).Pengaruh kinerja keuangan terhadap harga saham. JOURNAL OF BUSINESS STUDIES Vol.3 No.1 Juli 2018ISSN: 2443-3837

Indrayanti.(2018). Analisis Pengaruh Kebijakan Hutang , Investasi, Persistensi Laba, Pertumbuhan Perusahaan Terhadap 
Harga saham Perusahaan Di BEI 2015. Jurnal ISSN.

Jelie, D.W, Parengkuan T., \& Jeffry L.A.T.(2017). pengaruh Stuktur Modal, Ukuran Prusahaan dan Profitabilitas Terhadap Harga Saham. Jurnal EMBA Vol.5 No.3 September 2017, Hal.3385-3394 ISSN 2303-1174.

Kasmir.2012. Analisis Laporan Keuangan. Jakarta: PT Raja Grafindo Persada. 2015. Analisis Laporan Keuangan. Jakarta: PT Raja Grafindo Persada.

Lina, H,. W.(2017).The Effect of Market Valuation Measures on Stock PriceInternational Journal of Business and Social Science Vol. 8, No. 3; March 2017 ISSN 22191933 .

Martani, D. 2016 . Akuntansi Menengah Berbasis PSAK. Edisi 2. Jakarta: Salemba Empat.

Muktiadji, N., \& Ningrum, S.(2018).Analisis pengaruh basic earning power, stuktur modal dan kebijakan dividen terhadap harga saham .Jurnal Ilmiah Manajemen Kesatuan Vol. 6 No.1, 2018 pg. 045 -052 STIE Kesatuan .ISSN $2337-7860$.

Murdhaningsih, JMV. Mulyadi \& Adi, W.(2018).analisis pengaruh debt to equity ratio, return on equity,qurent ratio, operating profit margin dan inflasi terhadap harga saham JURNAL EKOBISMAN VOL 3. NO. 2 DESEMBER 2018 P-ISSN :2528-4304 EISSN ; 2597-9302.

Martina, R.,U., \& Arif, D.(2018). Effect of DER, ROA, ROE, EPS and MVA on Stock Prices.Journal of Applied Accounting and Taxation Article History Vol. 4, No. 1, 1522 ,2019 e-ISSN: 2548-9925.

Md. Bellal H., R., A.H.M.A.(2018). The Impact of Dividend Policy on Stock PriceJournal of Economics and Finance (IOSR-JEF) eISSN: 2321-5933, p-ISSN: 2321-5925

Neneng, T, A .(2018).Pengaruh Return On Asset, Return On Equity, Net Profit Margin dan Debt To Equity Ratio Terhadap Harga Saham ISSN (online) : 2581-2777 \& ISSN (print) : 2581-2696.

Octaviani, M., Marjam, M., \& Joy, E. T.(2018). Pengaruh Stuktur Modal, Kepemilikan Manajerial Dan Kebijakan Dividen Terhadap Harga Saham (Studi Kasus Pada Perusahaan Manufaktur Subsektor Food And Beverage Yang Terdadtar Di Bei Periode 2012-2016.Jurnal EMBA,ISSN 2303-1174.

Randi, B. G., Sukma, I., \& Mokhmad, T. (2018). Profitabilitas, Struktur Modal, Kebijakan
Dividen Pengaruhnya Terhadap Harga Saham Perusahaan. Jurnal E-ISSN.

Reiklof, P., Ivonne, S., \& Joubert, M. (2017) .Analisis Pengaruh Profitabilitas dan Stuktur Modal Terhadap Harga Saham .Jurnal EMBA Vol.5 No.3 September 2017, Hal. 3577 - 3582ISSN 2303-1174.

Soemarso, S.R. 2012. Akuntansi Suatu Pengantar. Edisi Kelima. Jakarta: Salemba empat.

Saleh, D. S. (2018). Pengaruh Operating Capacity, Arus Kas Operasi dan Biaya Variabel terhadap Financial Distress pada Perusahaan Manufaktur Subsektor Textil dan Garment yang Terdaftar di Bursa Efek Indonesia (Bei) Tahun 2009-2016. Eqien: Jurnal Ekonomi dan Bisnis, 5(1), 34-49.

Susanto, A. 2013. Sistem Informasi Akuntansi. Bandung : Lingga Jaya.

Sugiyono. (2014). Metode Penelitian Pendididkan Pendekatan Kuantitatif,Kualitati, dan $R \& D$. Bandung Alfabeta.

2017. Metode Penelitian Pendididkan Pendekatan Kuantitatif,Kualitati, dan $R \& D$. Bandung Alfabeta.

Sudana, I,M. (2015). Manajemen Keuangan Perusahaan. Kdisis Kedua Jakarta:Erlangga.

Samryn,LM. 2011. Pengantar Akuntansi. Edisis Pertama. Jakarta: Raja Grafindo Persada.

Suyono \& Yoki .(2018). Analisys Of Fundamental Ratios Effect On The Stock Price. KURS Vol. 3 No. 1, Juni 2018 e-ISSN 2527-8215.

Yunaningsih, N.,,Sri, M., \& Johan, R. T.(2016). : Analisis Ukuran Perusahaan, Stuktur Modal, Non Performing Loan (NPL), Capital Adequacy Ratio (CAR), Return on Equity (ROE).Jurnal EMBA Vol.4 No.3 September 2016, Hal. 717-728 ISSN 23031174.

https://m.cnnindonesia.com (diakses 15 maret 2019)

https://www.idx.co.id ( diakses 15 maret 2019)

https://www.sahamok.com ( diakses 15 maret 2019)

https://finance.yahoo.com ( diakses 16 maret 2019)

http://www.pakuwonjati.com/ ( diakses 17 maret 2019)

http://metropolitanland.com/id/home ( diakses 17 maret 2019)

https://www.modernland.co.id/ ( diakses 17 maret 2019)

https://gapuraprima.com/ ( diakses 17 maret 2019) http://www.lippo-cikarang.com/( diakses 17 maret 2019) 
https://www.megapolitan-group.com/ ( diakses 18 maret 2019)

https://www.agungpodomoroland.com/ ( diakses 18 maret 2019)

http://www.rodavivatex.co.id/ ( diakses 18 maret 2019)

https://www.pikkoland.com/en-home.html diakses 18 maret 2019)

http://www.summarecon.com/ ( diakses 18 maret 2019)

https://www.lippokarawaci.co.id/ ( diakses 18 maret 2019)

https://www.ciputradevelopment.com/id/ ( diakses 18 maret 2019) 